\title{
ASSESSMENT OF CARBON DIOXIDE EMISSIONS FROM DIFFERENT TILLAGE SYSTEMS
}

\author{
Alberts Auzins, Janis Kazotnieks, Ieva Leimane, Andris Miglavs \\ Institute of Agricultural Resources and Economics, Latvia \\ alberts.auzins@arei.lv, janis.kazotnieks@1lkc.lv,ieva.leimane@arei.lv, andris.miglavs@gmail.com
}

\begin{abstract}
The article presents the assessment of energy input and carbon dioxide emissions from fuel combustion (in tractor engine) in different tillage systems. Although the carbon dioxide emissions from fuel combustion are not typically included in the greenhouse gas (GHG) emissions from agriculture, these emissions are directly related to crop production practices and use of machinery. The aim of this study is to evaluate and compare efficiency of the energy input and carbon dioxide emissions from the fuel combustion in winter wheat cultivation considering different tillage systems. The calculations are based on empirical data provided by Latvian crop farmers. In addition, the environmental cost of these carbon dioxide emissions is evaluated as the external (socio-economic) cost of the emitted carbon dioxide by applying the unit cost (unit shadow price) of carbon dioxide. The winter wheat is the most widely produced crop in Latvia, and the results of this case study imply that there is a potential both to improve the efficiency of energy input and to mitigate the emissions of carbon dioxide by reducing the intensity of tillage in Latvian crop production. Reduced tillage needs significantly lower energy input and causes less carbon dioxide emissions (33-46\% on a per ha basis and $39-46 \%$ on a per tonne of wheat basis), as well as environmental cost than conventional tillage at the same time without significant differences in yields. Nevertheless, the debate on the long-term effects of conservation tillage systems on crop yields, crop diseases, weeds, etc. is open. Therefore, further research is required to assess other environmental aspects.
\end{abstract}

Keywords: tillage systems, crop production, GHG emissions, energy input.

\section{Introduction}

In response to climate change and that part of global warming, which is caused by human activity, the European Union (EU) Member States have agreed on the ambitious target to reduce greenhouse gas (GHG) emissions by 2030 significantly. Improving the efficiency of the utilization of production factors, like energy and fertilizers, are among the main activities of this complex process.

Agriculture is a significant source of global GHG emissions, it accounts for approximately $12 \%$ of the total anthropogenic emissions and they are projected to increase, driven by population and income growth and changes in consumption patterns [1]. According to the latest National Inventory Report (NIR), agriculture is the second largest GHG emission sector in Latvia and generates almost $20 \%$ (2609.4 kt $\mathrm{CO}_{2}$ eq. in 2018) of the total GHG emissions in the country [2]. There are $\mathrm{N}_{2} \mathrm{O}$ emissions from agricultural soils (59.3\% of total), $\mathrm{CH}_{4}$ emissions from enteric fermentation of domestic livestock (32.6\%), $\mathrm{CH}_{4}$ and $\mathrm{N}_{2} \mathrm{O}$ emissions from manure management (6.5\%), as well as $\mathrm{CO}_{2}$ emissions from liming and urea application (1.7\%) directly included in agricultural emissions [2]. Although the carbon dioxide $\left(\mathrm{CO}_{2}\right)$ emissions from fuel combustion are not typically included in the GHG emissions from agriculture, these emissions are also directly related to the land management practices and use of machinery. According to the NIR, carbon dioxide emissions from fuel combustion in agriculture and forestry were $372.7 \mathrm{kt} \mathrm{CO}_{2}$ eq. or $24 \%$, if compared to emissions from agricultural soils in 2018 in Latvia [2].

Considering the topicality, research analysing and empirically testing GHG emissions-reducing farming practices are worldwide known and there is growing evidence that mitigation can be gained through improved land management [3], where introduction of conservation tillage practice can play a significant role. Conservation tillage reduces soil organic matter loss, limits erosion, and significantly improves air and water circulation in soil, as compared to conventional tillage [4)-[6]], thereby positively influencing the physio-chemical and hydrothermal soil conditions, which control the GHG emissions [5]. On the other hand, as information on $\mathrm{N}_{2} \mathrm{O}$ emissions under long term no-tillage varies significantly, there are researches arguing that reduced tillage role in mitigation of climate changes is overstated [7].

While studies on the effects of conservation tillage on GHG formation do not provide unambiguous results in the short and long term, machinery fuel consumption among different tillage systems and the resulting GHG emissions can be evaluated accurately. The aim of this study is to assess the efficiency of energy input and carbon dioxide emissions from fuel usage, when conventional tillage is used and 
compare with two different types of reduced tillage systems based on empirical data provided by Latvian crop farmers. In addition, the environmental cost as the external (socio-economic) cost of these carbon dioxide emissions is evaluated. The study focuses on winter wheat production. Wheat is widely popular cereal worldwide, a common source of energy and protein with a production of 766 million tonnes and utilisation of 216 million ha of agricultural land in 2019 globally [8]. It is also the most popular crop in Latvia, with a production of 2.6 million tonnes and utilisation of 0.5 million ha of agricultural land in 2020 and the area is growing [9]. Wheat production is an energy intensive process and energy input varies under different treatments and production conditions [10], therefore, identification of the appropriate tillage practice having higher efficiency of energy input and possibly lower carbon dioxide emission is important both for farmers and society.

\section{Materials and methods}

The main data source for the study is unpublished information and empirical data obtained from the Latvian crop farmers within the agricultural European Innovation Partnership (EIP-AGRI) project "Progressive land cultivation system as the basis for environmentally friendly and effective crop production".

The following tillage systems have been analysed.

1. Conventional-till.

2. Strip-till with reduced tillage.

3. Strip-till.

All three of them were applied on different parts of the same filed with homogeneous soil characteristics and water regime.

The energy input is estimated as the diesel fuel consumption per hectare related to machinery operations. The following formula is used to calculate the fuel consumption for all tillage systems:

$$
C_{-} f_{i}=\sum_{j=1}^{m} n_{-} a t w_{i j} c_{-} a t w_{i j},
$$

where $\quad C_{-} f_{i}$-consumption of diesel fuel for tillage system $i, 1$ per ha;

$N_{\_} a t w_{i j}$ - number of machinery operation $\mathrm{j}$ for tillage system $i$, units;

$c \_a t w_{i j}$ - specific consumption of diesel fuel for machinery operation $j$ at tillage system $i$, 1 per ha.

The parameters $n \_a t w_{i j}$ and $c_{-} a t w_{i j}$ for all three tillage systems are derived from the empirical data obtained within the project. The key assumptions are presented in Table 1.

Table 1

Key assumptions for analysed tillage systems

\begin{tabular}{|c|c|c|c|c|c|c|}
\hline \multirow[t]{2}{*}{$\begin{array}{l}\text { Machinery } \\
\text { operations }\end{array}$} & \multicolumn{2}{|c|}{ Conventional-till } & \multicolumn{2}{|c|}{$\begin{array}{c}\text { Strip-till with reduced } \\
\text { tillage }\end{array}$} & \multicolumn{2}{|c|}{ Strip-till } \\
\hline & $n \_a t w$ & c_atw & $n \_a t w$ & c_atw & $n \_a t w$ & $c \_a t w$ \\
\hline Ploughing & 1 & 24.2 & $\mathrm{x}$ & $\mathrm{x}$ & $\mathrm{x}$ & $\mathrm{x}$ \\
\hline Stubble cultivation & $\mathrm{x}$ & $\mathrm{x}$ & 1 & 10.0 & $\mathrm{x}$ & $\mathrm{x}$ \\
\hline Levelling & 1 & 4.4 & $\mathrm{x}$ & $\mathrm{x}$ & $\mathrm{x}$ & $\mathrm{x}$ \\
\hline Sowing & 1 & 5.0 & 1 & 4.9 & 1 & 7.5 \\
\hline $\begin{array}{l}\text { Mineral fertiliser } \\
\text { spreading }\end{array}$ & 4 & 0.6 & 4 & 0.6 & 4 & 0.6 \\
\hline Pesticide spraying & 4 & 0.8 & 4 & 0.8 & 4 & 0.8 \\
\hline Combine harvesting & 1 & 17.7 & 1 & 17.7 & 1 & 17.7 \\
\hline$C_{-} f$ & $\mathbf{x}$ & 56.9 & $\mathbf{x}$ & 38.2 & $\mathbf{x}$ & 30.8 \\
\hline
\end{tabular}

Source: the data provided by the project's partners (year 2020)

In order to avoid overestimating the energy input in different tillage systems, the lower heating value (net calorific value) of diesel fuel is used to calculate the energy input. The use of lower heating 
value is also suggested by 2006 IPCC Guidelines for National Greenhouse Gas Inventories [11]. The following formula is used to calculate the energy input:

$$
E i_{i}=C_{-} f_{i} \cdot \rho_{d} \cdot q_{d},
$$

where $E i_{i}-$ energy input for tillage system $i, \mathrm{MJ}$ per ha;

$\rho_{d}$ - density of diesel fuel, kg per l;

$q_{d}$ - lower heating value of diesel fuel, MJ per $\mathrm{kg}$.

The density of diesel fuel and the lower heating value are not constant and depend on different factors. The density $(0.837 \mathrm{~kg}$ per 1$)$ specified by the Methodology for Calculating Greenhouse Gas Emissions is used in the study [12]. The lower heating value of diesel fuel is assumed $43 \mathrm{MJ}$ per $\mathrm{kg}$ according to 2006 IPCC Guidelines for National Greenhouse Gas Inventories and the Methodology for Calculating Greenhouse Gas Emissions [[11], [12]].

The carbon emissions from different tillage systems are estimated on the basis of $C_{-} f_{i}$ and $\mathrm{CO}_{2}$ emission factor for diesel fuel. $\mathrm{CO}_{2}$ emission factor for diesel fuel varies in different sources, e.g., 3.165 [13], 3.169 [14], 3.182 (recalculated value) [12], 3.186 (recalculated default value) [11] $\mathrm{kg} \mathrm{CO}_{2}$ per $\mathrm{kg}$ diesel fuel. The emissions factor is assumed $3.17 \mathrm{~kg} \mathrm{CO}_{2}$ per $\mathrm{kg}$ in the study. The emissions of other green-house gases $\left(\mathrm{CH}_{4}, \mathrm{~N}_{2} \mathrm{O}\right)$ from diesel fuel are not taken into account, as these emissions are not significant (expressed as $\mathrm{CO}_{2}$ equivalent) compared to $\mathrm{CO}_{2}$ emissions. The following formula is used to calculate the $\mathrm{CO}_{2}$ emissions from different tillage systems:

$$
\mathrm{Emi}_{i}=\mathrm{C}_{-} f_{i} \cdot \rho_{d} \cdot K_{\mathrm{CO} 2},
$$

where $E m i_{i}-\mathrm{CO} 2$ emissions for tillage system $i, \mathrm{~kg} \mathrm{CO} 2$ per ha;

$K_{\mathrm{CO} 2}-\mathrm{CO} 2$ emission factor for diesel fuel, $\mathrm{kg} \mathrm{CO} 2$ per $\mathrm{kg}$.

The environmental costs of the $\mathrm{CO}_{2}$ emissions for different tillage systems are evaluated as the external (socio-economic) costs of the emitted $\mathrm{CO}_{2}$ by applying the unit cost (unit shadow price) of carbon dioxide. According to the central estimate of the unit cost by the European Commission, the unite cost at 2021 is estimated 36 EUR per $\mathrm{CO}_{2}$ or 0.036 EUR per $\mathrm{kg} \mathrm{CO}_{2}$ [15].

The energy input, the $\mathrm{CO}_{2}$ emissions and the socio-economic costs of $\mathrm{CO}_{2}$ emissions are also calculated per tonne of winter wheat to assess the efficiency of tillage systems. According to the data provided by the farmers (year 2020), the yield of winter wheat was $6.0 \mathrm{t}$ per ha for conventional-till, $6.6 \mathrm{t}$ per ha for strip-till with reduced tillage (10\% higher than for conventional-till) and $6.0 \mathrm{t}$ per ha for strip-till system (the same as for conventional-till). These yield differences between conventional-till and conservation tillage correspond to to the study results reported by Sørensen et al., which show the relative yield of reduced tillage systems (relative to conventional-till) to be in the range of $88 \%$ to $110 \%$ [16].

\section{Results and discussion}

Based on the methodology, the data and the assumptions described above, the energy input and the $\mathrm{CO}_{2}$ emissions, as well as the socio-economic costs of $\mathrm{CO}_{2}$ emissions have been calculated for all three types of analysed tillage systems. The results are presented in Table 2.

The calculations indicate that the energy input and related to that $\mathrm{CO} 2$ emissions are $33 \%$ lower for strip-till with reduced tillage and $46 \%$ for strip-till system if compared on a per ha basis. As the yield difference appears to be not significant (see above), the results on a per tonne basis are very similar $39 \%$ and $46 \%$, respectively. These findings are consistent with the results of the study of Sørensen and Nielsen showing that reduced tillage systems can reduce energy input by 32-67\% [17]. Nevertheless, the results of the resent study reported by Sørensen et al. show the lower reduction in energy input - 28$29 \%$ caused by reduced tillage [16]. Therefore, further research is required to assess the energy input and $\mathrm{CO}_{2}$ emissions per unit of yield obtained when reduced tillage is applied on long-term basis.

As the socio-economic costs of $\mathrm{CO}_{2}$ emissions are directly related to the energy input, the relative difference among the analysed tillage systems is the same as the difference in energy input and $\mathrm{CO}_{2}$ emissions. Even though these socio-economic costs seem rather small per ha and per tonne of wheat, these costs are quite significant, if calculated at the national level. According to the Official Statistics of 
Latvia, the total area producing winter wheat in 2020 was 382.2 thousand ha [9]. Thus, the total socioeconomic costs account for 2.08 million EUR per year, if conventional-till is applied. The switching to strip-till with reduced tillage and strip-till has the potential to reduce the total socio-economic costs by 684.5 and 952.8 thousand EUR per year, respectively.

Table 2

\section{Energy input, $\mathrm{CO}_{2}$ emissions and the socio-economic cost from different tillage systems}

\begin{tabular}{|l|c|c|c|}
\hline \multicolumn{1}{|c|}{ Indicators } & Conventional-till & $\begin{array}{c}\text { Strip-till with } \\
\text { reduced tillage }\end{array}$ & Strip-till \\
\hline Energy input, MJ per ha & 2048 & 1373 & 1109 \\
\hline Energy input, MJ per t wheat & 341 & 208 & 185 \\
\hline $\mathrm{CO}_{2}$ emissions, kg per ha & 151 & 101 & 82 \\
\hline $\mathrm{CO}_{2}$ emissions, kg per t wheat & 25 & 15 & 14 \\
\hline $\begin{array}{l}\text { Socio-economic costs of the } \mathrm{CO}_{2} \\
\text { emissions, EUR per ha }\end{array}$ & 5.43 & 3.64 & 2.94 \\
\hline $\begin{array}{l}\text { Socio-economic costs of the } \mathrm{CO}_{2} \\
\text { emissions, EUR per t wheat }\end{array}$ & 0.91 & 0.55 & 0.49 \\
\hline
\end{tabular}

Source: the authors' calculations

Although there is some discrepancy between the findings of this study and the other studies (which may be caused also by the different soil conditions and agro-technology applied), the study allows concluding that the reduced tillage systems have a significant potential to reduce the input energy and $\mathrm{CO}_{2}$ emissions from fuel consumption in winter wheat cultivation.

Therefore, these tillage systems have a potential to contribute to the reduction of the $\mathrm{CO}_{2}$ emissions related to agriculture without significant effect on yields. Nevertheless, further research is required to explore the long-term effects of reduced tillage systems on crop yields, crop diseases, weeds, etc. in order to assess other environmental aspects. Crop rotation also should be considered.

\section{Conclusions}

1. The study shows that conservation tillage systems require lower energy input and cause less carbon dioxide emissions from fuel combustion as compared to the conventional-till - both on a per ha basis $(33-46 \%)$ and on a per tonne of wheat basis (39-46\%). The difference in yields appears to be not significant. Actually, reduced tillage systems have the same or even higher yield than conventional-till in short term.

2. The findings indicate that conservation tillage systems have a potential to contribute to the reduction of the carbon dioxide emissions related to agriculture without significant effect on the yields. However, further research (including field trials) is required to evaluate the stability of the results in long term.

3. According to the estimated total socio-economic costs of carbon emissions, switching to conservation tillage systems has a potential to reduce these environmental costs by 684.5 thousand EUR per year (if strip-till with reduced tillage applied) and 952.8 thousand EUR per year (if striptill applied) in Latvia. The actual potential is probably higher as these estimates consider only the area producing winter wheat.

4. The debate on the long-term effects conservation tillage systems on crop yields, crop diseases, weeds, etc. is still open, also its relation to crop rotation practices. Therefore, further research is required to address these issues and to assess other environmental aspects.

\section{Acknowledgements}

The paper was prepared in the framework of the European Innovation Partnership (EIP-AGRI) project "Progressive land cultivation system as the basis for environmentally friendly and effective crop production". 


\section{References}

[1] Special Report on Climate Change and Land. IPCC, 2019. [online] [18.03.2021]. Available at: https://www.ipcc.ch/site/assets/uploads/sites/4/2021/02/210202-IPCCJ7230-SRCCL-CompleteBOOK-HRES.pdf

[2] Latvia's National Inventory Report, 1990 - 2018, pp 491. [online] [05.03.2021]. Available at: ftp://ftp2.meteo.lv/Klimats/SEG_emisiju_un_ETS_monitorings/Zinojums_par_klimatu/SEG_zino jums/2020

[3] Griscom B.W. et al. Natural climate solutions. Proceedings of the National Academy of Sciences, 114 (44), 2017, pp. 11645-11650

[4] Agriculture and climate change Reducing emissions through improved farming practices, McKinsey \& Company, 2020. [online] [18.03.2021]. Available at:

https://www.mckinsey.com/industries/agriculture/our-insights/reducing-agriculture-emissionsthrough-improved-farming-practices\#

[5] Alskaf K., Mooney S.J., Sparkes D.L., Wilson P., Sjögersten S. Short-term impacts of different tillage practices and plant residue retention on soil physical properties and greenhouse gas emissions. Soil and Tillage Research, 206, 2021, 104803

[6] Mangalassery S., Sjogersten S., Sparkes D., Mooney S. Examining the potential for climate change mitigation from zero tillage. The Journal of Agricultural Science, 153 (7), 2015, pp. 1151-1173

[7] Powlson D., Stirling C., Jat M. et al. Limited potential of no-till agriculture for climate change mitigation. Nature Clim Change, 4, 2014, pp. 678-683

[8] FAOSTAT agricultural data. [online] [17.03.2021]. Available at: http://www.fao.org

[9] Official Statistics of Latvia. [online] [17.03.2021]. Available at: https://data.stat.gov.lv/pxweb/en/OSP_PUB/START_NOZ_LA_LAG/LAG020/

[10] Nasseri A. Energy use and economic analysis for wheat production by conservation tillage along with sprinkler irrigation. Science of The Total Environment, 648, 2019, pp. 450-459

[11] Guidelines for National Greenhouse Gas Inventories. Intergovernmental Panel on Climate Change IPCC, 2006. [online] [05.03.2021] Available at: https://www.ipcc-nggip.iges.or.jp/public/2006gl/

[12] Methodology for Calculating Greenhouse Gas Emissions. Republic of Latvia Cabinet Regulation No. 42, Latvia, 2018. [online] [06.03.2021] Available at: https://likumi.lv/ta/en/en/id/296651methodology-for-calculating-greenhouse-gas-emissions

[13] Juhrich K. $\mathrm{CO}_{2}$ Emission Factors for Fossil Fuels, German Environment Agency (UBA), 2016, 48 p. [online] [06.03.2021] Available at: https://www.umweltbundesamt.de/sites/default/files/medien/1968/publikationen/co2_emission_fa ctors_for_fossil_fuels_correction.pdf

[14] EMEP/EEA air pollutant emission inventory guidebook 2019, 2020, pp 142. [online] [06.03.2021] Available at: https://www.eea.europa.eu/publications/emep-eea-guidebook-2019/part-b-sectoralguidance-chapters/1-energy/1-a-combustion/1-a-3-b-i/view

[15] Guide to Cost-Benefit Analysis of Investment Projects, European Union, 2015, pp 364. [online] [06.03.2021] Available at: http://ec.europa.eu/regional_policy/sources/docgener/studies/pdf/cba_guide.pdf

[16] Sørensen C.G., Halberg N., Oudshoorn F.W., Petersen B.M., Dalgaard R. Energy inputs and GHG emissions of tillage systems. Biosystems Engineering, 120, 2014, pp. 2-14

[17] Sørensen C.G., Nielsen V. Operational Analyses and Model Comparison of Machinery Systems for Reduced Tillage. Biosystems Engineering, 92, (2), 2005, pp. 143-155 